\title{
DEVELOPING CRITICAL THINKING SKILLS IN INFORMATION SYSTEMS MAJORS THROUGH PEER REVIEW
}

\author{
Judy Wynekoop, Florida Gulf Coast University, jwynekoo@fgcu.edu \\ Kazuo Nakatani, Florida Gulf Coast University, knakatan@fgcu.edu
}

\begin{abstract}
This study investigates the effectiveness of pedagogical techniques, reflection and peer review, designed to improve critical thinking skills in Information System majors. The paper presents the results of an exploratory study of the effect of self-reflection and peer review on information systems students' critical thinking ability in a systems analysis and design class. Results support the use of these pedagogical interventions to improve students' critical thinking ability, as well as their content knowledge.
\end{abstract}

Keywords: critical thinking; reflection; metacognition; peer review

\section{INTRODUCTION}

Although accrediting bodies, employers and business colleges emphasize the importance of the ability for business majors to be able to think critically (AACSB, 2018; Jones, Leonard, \& Lang, 2018; Topi, et al., 2010; Wall Street Journal, 2010), colleges struggle to develop students' critical thinking abilities (Arum \& Roksa, 2011), and researchers have found that undergraduates' critical thinking skills may actually diminish while in college (Phan, 2011).

Critical thinking can be learned (Halpern, 1998), although how to effectively embed the skills in business and information systems curricula and how to assess them are not clear (Bandyopadhyay \& Szostek, 2019; Pomykalski, 2006). Additionally, perseverance is required to develop and apply critical thinking skills (Halpern, 1998). To be most effective, critical thinking must involve conscious self-reflection and critique of one's thinking, or metacognition (Schoenberg, 2015).

\section{CRITICAL THINKING}

Critical thinkers are open minded, able to interpret and analyze information in a variety of settings, evaluate the credibility of information, infer the consequences of a decision, and justify their reasoning effectively (Halpern, 1998). In business education research, critical thinking skills have been defined as the ability to evaluate sources of information, challenge assumptions, understand context, analyze arguments, and use metacognition (Brown \& Bielinska-Kwapisz, 2015).

Success at critical thinking and writing are intertwined (Bailey, Zanchetta, Velasco, \& Pon, 2015). AACSBInternational, an accrediting body for business schools, notes that business students should be able to demonstrate "higher-order cognitive skills to analyze an unstructured problem, formulate and develop a solution using appropriate technology, and effectively communicate the results to stakeholders” (AACSB, 2018, p. 35). A key aspect of becoming a critical thinker is reflecting on, and critiquing, one's own thinking (Paul \& Elder, 2001; Schoenberg, 2015). Students can enhance their critical thinking skills by being actively involved in improving their own thinking and becoming more effective critics of their own thinking. Teaching critical thinking should provide sufficient opportunities for students to reflect on, and improve their thinking (Celuch \& Slama, 1999).

Critical thinking interventions have been studied in a variety of disciplines. For example, Bernstein and Greenhoot (2014) describe a large-scale intervention in psychology and political science classes involving teams of learning specialist and faculty, and, based on results from the AAC\&U Value Rubrics for critical thinking and writing rubrics, found improvement in students' skills over time. Others examine the total effect of an overall business education on critical thinking. Brown and Bielinska-Kwapisz (2015) administered the California Critical Thinking Skills Test (CCTST) to graduating seniors in the business college and conclude that the academic curriculum influences critical thinking scores. However, some have questioned whether the business curriculum improves 


\section{Issues in Information Systems}

Volume 21, Issue 1, pp. 195-201, 2020

critical thinking or filters out students without higher order thinking skills (Coleman, Mason, \& Steagall, 2012). There is some evidence that specific courses or modules to teach critical thinking skills may be useful (Reid \& Anderson, 2012), although it has been stressed that the most important critical thinking competencies must be addressed throughout the curriculum (Elder \& Paul, 2010).

There has been some study of improving higher order, critical, and analytical thinking in the Information Systems (IS) curriculum. Most studies have been done using interventions in existing IS courses, since there are few specific courses for critical thinking in information systems. In one such standalone course that explicitly teaches higher order thinking and problem solving techniques in class and enforces the concepts in normal IS assignments (e.g. reports, systems analysis and development, and programming), students reported that their ability to think critically was improved, and both students and lecturers believed peer review was beneficial (Davis, Thomas, \& Kazlaukas, 2006). Few reports of critical thinking pedagogical interventions in IS classes have been quantitatively assessed.

Reflective writing has also been used in IS courses to teach higher order thinking (Wang \& Wang, 2011). Students in an introductory MIS course were given an overview of critical thinking, systems thinking, and design thinking early in the course and then asked to apply various models supporting the three types of higher order thinking to situations (e.g. the SDLC, business process reengineering, decision-making models) throughout the course. Students wrote a case analysis, reflection paper, and a self-evaluation of their higher-order thinking ability. Papers scoring highest in both the treatment and control groups were evaluated by the instructors for improvement in critical thinking. Reports of students in the group that used the method were significantly better than those written by students who did not (Wang \& Wang, 2011).

Pomykalski (2006) required students to write a memo to a user describing a graphical model, such as an entityrelationship diagram, its purpose, and its meaning in a systems analysis and design class and concluded that the activity allowed students to think critically, as well as communicate effectively. However, no quantitative or qualitative assessments were reported.

Peer assessment requires the evaluator to analyze the work product, evaluate it, and explain what is wrong with it, thus practicing evaluative elements of critical thinking (van den Berg, Admiraal, \& Pilot, 2006) and it has been shown to be related to improved critical thinking (Garcia \& Pintrich, 1992). The use of peer-review in a systems analysis and design class was found to improve students' critical thinking ability (Lavy \& Yadin, 2010), based on student comments. Students were required to assess other students' projects and were evaluated on their assessments.

There has been ambivalence on how to best measure critical thinking in the classroom (Bandyopadhyay \& Szostek, 2019). Research has indicated critical thinking may be best assessed using multiple methods in multiple settings (Halpern, 1998). Standardized instruments that have been used include the Watson-Glaser a Thinking Appraisal (Watson \& Glaser, 1964), the BCCTST (Business California Critical Thinking Skills Test), and the HEIghten Critical Thinking Assessment (https://www.ets.org). These assessments all measure various dimensions of critical thinking, such as deductive and inductive reasoning, reasoning and evaluation ability, and interpretation and inference skills. Other studies have used student self-assessment (Davis, Thomas, \& Kazlaukas, 2006), instructor assessment (Pomykalski, 2006; Wang \& Wang, 2011), college rubrics (Bandyopadhyay \& Szostek, 2019), and instructor use of AAC\&U Value Rubrics (Bernstein \& Greenhoot, 2014).

Thus, prior work shows the potential of reflective thinking implemented by business memos and peer review in improving student's critical thinking skills. Thus, this study addresses the following research question: Does the combination of reflective thinking papers with peer review improve CIS majors' critical thinking?

With the exception of (Wang \& Wang, 2011), studies of embedding critical thinking pedagogy into information systems courses largely measure improvement by asking students or instructors if they believe critical thinking has improved. This study assesses the proposition that the combination of self-reflection and peer-evaluation activities enbedded in an information systems course will improve IS student's critical thinking ability using the AAC\&U Value Rubrics for critical thinking and writing. 


\section{Issues in Information Systems}

Volume 21, Issue 1, pp. 195-201, 2020

That is,

Proposition 1: Students who write reflective explanatory memos and practice peer review will demonstrate better critical thinking skills than those who do not.

\section{METHODOLOGY}

This study was conducted in a Systems Analysis and Design course for senior IS majors during Spring and Fall 2019. The course focuses on developing systems using adaptive methodologies and UML (Unified Modeling Language) modeling. During the semester, students do in-class exercises modeling scenarios with various types of UML diagrams. The pedagogical techniques assessed in this study, reflective thinking and peer review, were introduced in Fall 2019. Reflective thinking was implemented by students writing a memo explaining a graphical model, as proposed by Pomykalski (2006). Peer review was accomplished by having students critique memos written by their peers similar to Lavy and Yadin (2010). These activities were expected to improve students' critical thinking skills.

In Spring 2019 students submitted their diagrams and were given a grade by the instructor; there was no reflection or peer review. Early in the Fall 2019 semester critical thinking, systems thinking, and design thinking, was explained in class and related to information systems. In four of the in-class assignments, not only were students asked to model a given scenario, but they were also asked to write a brief memo to a client explaining the model. Table 1 shows the requirements for the memos. For all memos, students were instructed to write a professional business memo no longer than one page to a client who knew nothing about the systems development process. This learning activity was intended to implement reflective thinking by having students analyze their models and ensure they modeled the scenario accurately.

Table 1. Requirements for Memos of In-Class Assignments and Peer Review

\begin{tabular}{|c|c|c|c|}
\hline & \multicolumn{3}{|c|}{ Assessed By } \\
\hline Requirements for Memos & Student & Peer & Instructor \\
\hline $\begin{array}{l}\text { 1. Activity Diagram (AD): } \\
\text { - Describe the scenario \& why an AD is appropriate (its purpose \& role). } \\
\text { - A brief description of what your AD shows. }\end{array}$ & $\mathrm{x}$ & & $\mathrm{x}$ \\
\hline $\begin{array}{l}\text { 2. Use Case Diagram (UCD): } \\
\text { - Describe the problem \& purpose of a UCD in this situation. } \\
\text { - Describe the actors in your diagram \& how they interact with the system. }\end{array}$ & & $\mathrm{x}$ & $\mathrm{x}$ \\
\hline $\begin{array}{l}\text { 3. Domain Class Diagram (DCD): } \\
\text { - Describe the purpose of the DCD (i.e. why did you draw this instead of } \\
\text { something else?). } \\
\text { - Explain exactly what your diagram shows to your client. } \\
\text { - Explain how the DCD fits into the development process for the system in the } \\
\text { scenario. }\end{array}$ & & $\mathrm{x}$ & $\mathrm{X}$ \\
\hline $\begin{array}{l}\text { 4. Given an activity diagram \& systems sequence diagram modeling a scenario, } \\
\text { explain: } \\
\text { - What each of the diagrams is and what each is used for. } \\
\text { - Walk your client through each diagram. }\end{array}$ & & $\mathrm{x}$ & $\mathrm{x}$ \\
\hline
\end{tabular}

In the first assignment in Fall 2019, students modeled a scenario using an activity diagram and wrote a memo to a client explaining it. To introduce students to how to reflect and critically evaluate, this memo was assessed for critical thinking separately by both the student and the instructor, but not by a peer. In short, the self-assessment in the first assignment prepared students for conducting peer review in the next three assignments. The instructor used a modified AAC\&U rubric (Asociation of American Colleges and Universities, 2009) to assess critical thinking (Table 2).

The last three memos were assessed by a randomly assigned, anonymous classmate. In the peer review, the evaluator was asked to analyze the memo with respect to the model, evaluate it, and explain any errors. This learning activity 
was intended to practice evaluative elements of critical thinking. In the last activity, students did not draw the diagram themselves; students only wrote the memo.

Students were given the following simplified rubric to evaluate their own work for the first assignment (criteria were evaluated as “Almost Perfect”, “OK - some problems”, or "Needs work- good try”):

- $\quad$ Content Development - Did you use the right information in a way that made sense?

- Analysis \& Conclusion - Did you look at the information critically and was the conclusion logical and justified by the evidence?

Table 2. Modified AAC\&U Rubric Used by Instructor

\begin{tabular}{|c|c|c|c|c|}
\hline & Skilled & Satisfactory & Needs Improvement & Minimal \\
\hline $\begin{array}{l}\text { Content } \\
\text { Development } \\
\text { Is your problem/op } \\
\text { clearly stated? Do } \\
\text { you use evidence, facts } \\
\text { \& info in a way that } \\
\text { makes sense? Is your } \\
\text { argument logical? }\end{array}$ & $\begin{array}{l}\text { Uses relevant and } \\
\text { compelling content \& } \\
\text { evidence to address the } \\
\text { problem or opportunity, } \\
\text { showing mastery of the } \\
\text { subject; critical analysis } \\
\text { and synthesis skills } \\
\text { show understanding. }\end{array}$ & $\begin{array}{l}\text { Uses relevant and } \\
\text { compelling content to } \\
\text { address the problem } \\
\text { or opportunity, using } \\
\text { critical thinking skills } \\
\text { within the context of } \\
\text { the business or the } \\
\text { discipline. }\end{array}$ & $\begin{array}{l}\text { Uses relevant content } \\
\text { to develop and } \\
\text { explore ideas relating } \\
\text { to the problem or } \\
\text { opportunity through } \\
\text { most of the work. }\end{array}$ & $\begin{array}{l}\text { Uses relevant } \\
\text { content to } \\
\text { develop simple } \\
\text { ideas in some } \\
\text { parts of the } \\
\text { work. }\end{array}$ \\
\hline $\begin{array}{l}\text { Analysis \& } \\
\text { Conclusion } \\
\text { Do you look at the info } \\
\text { and evidence critically } \\
\text { and does your analysis } \\
\text { logically lead to your } \\
\text { conclusion? }\end{array}$ & $\begin{array}{l}\text { Skillfully analyzes and } \\
\text { evaluates information / } \\
\text { evidence related to } \\
\text { thesis; conclusion is } \\
\text { insightful, logical and } \\
\text { justified based on a } \\
\text { skillful evaluation of } \\
\text { evidence. }\end{array}$ & $\begin{array}{l}\text { Adequately analyzes } \\
\text { and evaluates } \\
\text { information / } \\
\text { evidence related to } \\
\text { thesis; conclusion is } \\
\text { logical and justified } \\
\text { based on evaluation } \\
\text { of evidence. }\end{array}$ & $\begin{array}{l}\text { Attempts to analyze } \\
\text { and evaluate } \\
\text { information / } \\
\text { evidence related to } \\
\text { thesis and use the } \\
\text { evidence in order to } \\
\text { justify conclusions. }\end{array}$ & $\begin{array}{l}\text { Little attempt to } \\
\text { evaluate quality } \\
\text { of information / } \\
\text { evidence or } \\
\text { support } \\
\text { conclusions. }\end{array}$ \\
\hline
\end{tabular}

In the remaining assignments, critical thinking in the memos was assessed on the same two criteria by a randomly assigned peer. Peer assessments were double blind and used the following scale:

- Almost Perfect: Uses relevant and compelling content \& evidence, showing mastery of the subject; analysis and synthesis skills show understanding. Information \& facts presented are completely correct.

- OK- Some Problems: Uses relevant content \& adequate analysis \& synthesis. Seems to understand the subject adequately. Information \& facts presented are mostly correct.

- Needs Work: Tries to use appropriate and relevant content to develop and explore ideas in some of the work. Seems uncertain of the subject. Information \& facts presented are questionable.

The instructor reviewed peer evaluations for reasonableness and gave students a grade on the diagram and the memo, partially informed by the peer assessment. To try to ensure students approached the peer review process seriously, the instructor also evaluated students on the following three characteristics of the feedback provided in their peer review:

- Comments and criticism are constructive.

- Comments are not degrading.

- Proper terminology used.

Near the end of each semester, students wrote a research report in which they analyzed a given scenario and recommended and justified a development approach, incorporating information from external sources. The instructor evaluated these reports using the modified AAC\&U rubric in Table 2. 


\section{DATA COLLECTION}

This study compares critical thinking ability from Spring 2019 (no reflection and peer review activities) with those from Fall 2019 (with reflective thinking and peer review activities). Students' critical thinking ability in the final research report was measured using the AAC\&U rubric. To see the impact of the learning activities on the student's modeling skills, data were also collected from the final exam. In each semester, 24 students were assessed.

\section{RESULTS}

The scores of the research reports are summarized in Table 3. Skilled and Satisfactory evaluations were considered acceptable levels of critical thinking skills. Therefore, the percentage of students scoring Needs Improvement and Minimal were expected to be less in Fall 2019 than in Spring 2019. As can be seen in Table 3, for both Content Development and Analysis \& Conclusion, the two measures of critical thinking in the AAC\&U rubric, while 25\% of students in Spring 2019 were evaluated as "Needs Improvement”, in Fall 2019, only 12\% needed improvement on the Content Development criterion and 16\% on the Analysis \& Conclusion criterion. This indicates that the combined reflection and peer review activities improved students’ critical thinking ability.

Table 3. Critical Thinking Assessment Results

\begin{tabular}{|c|c|c|c|c|c|c|c|c|}
\hline & \multicolumn{2}{|c|}{ Skilled } & \multicolumn{2}{|c|}{ Satisfactory } & \multicolumn{2}{|c|}{$\begin{array}{c}\text { Needs } \\
\text { Improvement }\end{array}$} & \multicolumn{2}{|c|}{ Minimal } \\
\hline & $\begin{array}{c}\text { Spring } \\
2019\end{array}$ & $\begin{array}{c}\text { Fall } \\
2019\end{array}$ & $\begin{array}{c}\text { Spring } \\
2019\end{array}$ & $\begin{array}{l}\text { Fall } \\
2019\end{array}$ & $\begin{array}{c}\text { Spring } \\
2019\end{array}$ & $\begin{array}{c}\text { Fall } \\
2019\end{array}$ & $\begin{array}{c}\text { Spring } \\
2019\end{array}$ & $\begin{array}{l}\text { Fall } \\
2019\end{array}$ \\
\hline Content Development & $12.5 \%$ & $8.0 \%$ & $62.5 \%$ & $80.0 \%$ & $25.0 \%$ & $12.0 \%$ & $0.0 \%$ & $0.0 \%$ \\
\hline Analysis \& Conclusion & $8.3 \%$ & $24.0 \%$ & $66.7 \%$ & $60.0 \%$ & $25.0 \%$ & $16.0 \%$ & $0.0 \%$ & $0.0 \%$ \\
\hline
\end{tabular}

Additionally, the self-reflection memo writing and peer-review exercises may have improved students' understanding of course content and modelling skills. The final exam in both classes included identical scenarios and required students to model that scenario using different UML diagrams. Students in Fall 2019 performed slightly better on these questions than did students in Spring 2019 (Table 4).

Table 4. Comparison of Final Exam Scenario Scores

\begin{tabular}{|l|c|c|}
\hline & Spring 2019 & Fall 2019 \\
\hline Mean score & $61 \%$ & $65 \%$ \\
\hline Median score & $61 \%$ & $69 \%$ \\
\hline
\end{tabular}

\section{SUMMARY AND LIMITATIONS}

This exploratory study found that a pedagogical intervention using reflective thinking and peer review in a systems analysis and design class had a positive impact on information systems majors' critical thinking skills. Students wrote business memos describing their models to a client and evaluated their own critical thinking, as well as that of their peers. Students practicing self and peer evaluation performed better on a critical thinking assessment of a research paper than did those who completed the same modeling exercises without writing or critiquing memos.

Results of this exploratory study are of limited generalizability and should be explored on a larger scale in IS curricula at different universities as well as in other disciplines. The convenience sample was small (48) and critical thinking ability was assessed using a limited rubric. As in most of the studies embedding critical thinking into an existing course (e.g. Pomykalski, 2006; Wang \& Wang, 2011), student reports were evaluated only by the course instructor, and therefore vulnerable to bias. In the future, critical thinking should be assessed by multiple evaluators with a more comprehensive rubric or a standardized test. 


\section{Issues in Information Systems}

Volume 21, Issue 1, pp. 195-201, 2020

Despite the limitations, this study expanded on previous work that demonstrated the use of peer review or reflection to improve critical thinking when embedded in an information systems course. Combining reflective writing and peer review may be used to enhance critical thinking, as well as domain knowledge. Incorporating such techniques throughout the information systems curriculum may be useful to provide sufficient opportunities for students to reflect on (Celuch \& Slama, 1999), as well as incorporating key critical thinking competencies throughout the curriculum (Elder \& Paul, 2010).

\section{REFERENCES}

AACSB. (2018). 2013 Eligibility Procedures and Accreditation Standards for Business Accreditation. Tampa: AACSB.

Arum, R., \& Roksa, J. (2011). Academically Adrift. Chicago, IL: University of Chicago Press.

Association of American Colleges and Universities. (2009). Critical Thinking VALUE Rubric. Retrieved from https://www.aacu.org/value/rubrics/critical-thinking

Bailey, A., Zanchetta, M., Velasco, D., \& Pon, G. (2015). Building a scholar in writing (BSW): A model for developing students' critical writing skills. Nurse Education in Practice, 15, 524-529.

Bandyopadhyay, S., \& Szostek, J. (2019). Thinking critically about critical thinking: Assessing critical thinking of business students using multiple measures. Journal of Education for Business, 94(4), 259-270.

Brown, F. W., \& Bielinska-Kwapisz, A. (2015). Understanding the Nature and Determinants of Critical Thinking among Senior Business Undergraduate Students. Journal of Education for Business, 90, 359-368.

Celuch, K., \& Slama, M. (1999). Teaching Critical Thinking Skills for the 21st Century: An Advertising Principles Case Study. Journal of Education for Business, 74(3), 134-139.

Coleman, B.J., P., Mason, \& Steagall, J.W. (2012). Does a business curriculum develop or filter critical thinking? American Journal of Business Education, 5(4), 409-415.

Davis, T., Thomas, T., \& Kazlaukas, A. (2006). What were you thinking? empowering tomorrow's professionals today. International Journal of Pedagogies and Learning, 2(1), 35-47.

Elder, L. \& Paul, R. (2010) Critical thinking: Competency standards essential for the cultivation of intellectual skills, part 1. Journal of Developmental Education, 34(2), 38-39.

Garcia, T., \& Pintrich, P. R. (1992). Critical thinking and its relationship to motivation, learning strategies, and classroom experience. 100th Annual Meeting of the American Pyschological Association. Washington, D.C.

Halpern, D. (1998). Teaching critical thinking for transfer across domains. American Psychologist, 53(4), 449-455.

Jones, K., Leonard, L., \& Lang, G. (2018). Desired skills for entry level IS positions: Identification and assessment. Journal of Computer Information Systems, 58(3), 214-220.

Lavy, I., \& Yadin, A. (2010). Team-based peer review as a form of formative assessment - the case of a systems analysis and design workshop. Journal of Information Systems Eductaion, 21(1), 85-98.

Paul, R., \& Elder, L. (2001). Critical thinking: tools for taking charge of your learning and your life. Saddle River: Prentice Hall.

Phan, H. (2011). Deep processing strategies and critical thinking: developmental trajectories using latent growth analyses. The Journal of Educational Research, 104, 283-294.

Pomykalski, J. J. (2006). Interleaving modeling and writing activities in systems analysis and design. Journal of Information Systems Education, 17(3), 249-252. 


\section{Issues in Information Systems}

Volume 21, Issue 1, pp. 195-201, 2020

Reid, J.R \& Anderson, P.R. (2012). Critical thinking in the business classroom. Journal of Education for Business, 87 (1), 52-59

Schoenberg, B. (2015). Critical Thinking in Business, Second Ed. Saint Charles: Heuristic Books, Science \& Humanities Press.

van den Berg, I., Admiraal, W., \& Pilot, A. (2006). Designing student peer assessment in higher education: analysis of written and oral peer feedback. Teaching in Higher Education, 11(2), 135-147.

Wall Street Journal. (2010, September 13). Schools' Rankings Calculated From 479 Recruiter Responses.

Wang, S., \& Wang, H. (2011). Teaching higher order thinking in the introductory MIS course: a model-direted approach. Journal of Education for Business, 86(4), 208-213. 